\title{
THE COMPARISON BETWEEN MALE AND FEMALE STUDENTS IN READING COMPREHENSION ACHIEVEMENT AT THE THIRD SEMESTER OF TBI STAIN PAMEKASAN
}

\author{
Kimsiyatur Rahmawati ${ }^{1}$ \\ ${ }^{1}$ English Teaching Learning Program, Tarbiyah Faculty, Institut Agama Islam Negeri Madura \\ S. Sumihatul Ummah' \\ 2 Islamic Early Childhood Education, Tarbiyah Faculty, Institut Agama Islam Negeri Madura
}

\begin{abstract}
The students of STAIN Pamekasan consist of male and female students. Each of them shows different abilities. Male students generally have a good performance on spatial tasks and mathematical achievement. While, female students are superior in some aspects such as mathematic calculation, vocabulary, found an idea, memorizing, and making a relation, several verbal skills, reading, and writing. This study examines to know the different achievements between male and female students in reading comprehension in the third semester of TBI STAIN Pamekasan and to measure the statistically significant difference between male and female students in reading comprehension achievement at the third semester of TBI STAIN Pamekasan. This research is designed with ex-post facto. The population is 210 students, and 82 students were chosen as sample. The research instruments were tests and documentation. The quantitative data will be analyzed using a t-test. The result showed that there is no difference between male and female students in reading comprehension achievement in the third semester of TBI STAIN Pamekasan. $t$-value is lower than $t$-table $[-1,226<2,64$ $(1 \%)][1,226<1,99(5 \%)]$. Based on the result above, the lecturer needs to pay attention more to the students' improvement in studying English, especially in reading comprehension.
\end{abstract}

Keywords: Comparison; Female; Male; Reading Comprehension

First Received:

(March 11, 2020)
Final Proof Received:

(March 23, 2020)

\section{INTRODUCTION}

Most studies show that, on average, females do better in school than males. Females get higher grades and complete high school at a higher rate compared males (Zembar \& Blume, 2011). It proves by generally at every grade females superior in class. Females not only active during learning process but also they can get higher score than male on test. Even females score significantly higher than males on almost all of tests measuring achievement. It shows that females can do better than male in learning.

Furthermore, females are better than males on several verbal skill tasks. According to Hedges and Nowell females are better on verbal reasoning, verbal fluency, comprehension, and understand logical relations. That is why females commonly are 
assumed talkative. While Wilder and Powel state that females are better on memory. Females have good memory; they can remember what they know.

In case of language learning, males and females may not have equal ability. It is in line with the statement of Sunderland that female students are in general more successful in language learning than male (Y. A. Al-Shumaimeri, 2005: 15). Females are easy to learn language, moreover to a new language because they sensitive in language. Females might be better at L2 learning than males (Ellis, 1994: 202). They can learn language by society or by learning in class faster and better than male. Females are superior to males in almost all of test measuring achievement it can be cause of the reading habit and reading comprehension of females are better than males.

Reading is receptive skill through it the reader receives information, getting knowledge, even pleasure and experience. It is one of ways to improve the reader general language skill in English. It can help the reader to learn thing, enlarge the reader English vocabulary, and improve writing skill. It may be a good way to practice English, and also a good way to find out about new ideas, facts, and experiences. The readers will get the advantages of reading if they can comprehend the reading material that they read. Reading comprehension is the process of constructing meaning by integrating the information provided by an author with the readers' background knowledge (Vaughn \& S. Bos, 2012: 248). Comprehension is the most important thing and the final goal of reading instruction. During reading the readers interact with the text to construct the meaning and to understand the ideas and information about the reading text. But not all readers can get it. Readers usually get difficulties to comprehend the reading text, even they forget what they have just read without understand the message in the reading material they read. There are some reasons why the readers especially students may have difficulty comprehending on what they read, such as focusing on building word identification, language disability (difficulty in syntax and semantics), and failure to relate what they are reading to what they have known about a topic.

Language ability is an important factor that affects comprehension. Having good language ability can help reader especially learner achieve good reading comprehension. Beside language ability, there are some factors that can influence the reading achievement of individual. According to Brantmeier, Bugel and bunk, gender, prior knowledge, and language ability have been seen as almost the major factors that influence reading comprehension performance (Y.A. Al-Shumaimeri, 2005: 5).

Many studies found that there is different achievement between male and female in reading comprehension. In fact, Female usually has better achievement on reading comprehension than males. PISA (Program for International Students Assessment test measures reading, mathematical and scientific literacy carried out in 2000, 2003, and 2006. It studies of 15-year olds in 27 countries in 2000, and 40 in 2003 and 56 countries in 2006. It found on its three studies that in reading comprehension females 
obtained higher average scores than males in all countries (Lynn \& Mikk, 2009: 5-7). In addition, PIRLS study (Progress in International Reading Literacy Study evaluated reading achievement of fourth grade students (10-year olds in 35 countries in 2006 and 40 countries in 2007 found in all countries females achieved significantly higher test result than males.

The fact that the researcher found that in all classes of reading 3 subject of TBI STAIN Pamekasan, the students' score of reading 3 over score 60 most of them are females. Moreover, in some classes the students that got highest midterm test score are females. The problems of study in this research to investigate whether male and female students at the third semester of TBI STAIN Pamekasan have difference achievement in reading comprehension, is there any statistically significant difference between male and female students in reading comprehension achievement at the third semester of TBI STAIN Pamekasan.

\section{LITERATURE REVIEW}

\section{Notion of Sex}

Sex is stated of being male or female. Sometimes is hard to understand exactly what is meant by the term sex, and how it differs from the term gender. Janet Holmes use the two terms in different case. Sex has come to refer to categories distinguished by biological characteristics, while gender is more appropriate for distinguishing people on the basis of their socio-cultural behavior (Holmes, 2001: 150). Sex refers to the biological and physiological characteristics that define male and female. Gender refers to the socially constructed roles, behaviors, activities, and attributes that a given society considers appropriate for male and female. So, male and female are categories of sex, while masculine and feminine are categories of gender.

a. Ability of Male and Female

Male and female have different ability. They may not have equal ability. There is some ability that only superior by one of them. Generally female are superior in some aspects, such as mathematic calculation, vocabulary, found an idea, memoriam, and making relation (Janson, 2010: 53). Besides that, females outperform males on several verbal skill tasks: verbal reasoning, verbal fluency, comprehension, and understanding logical relation (Zembar \& Blume, 2011: 1). In addition, Santrock in Rifa Hidayah states that females are better in reading and writing while in elementary and junior high school(Hidayah, 2012: 65).

Males generally have good performance on spatial tasks such as, mental rotation, spatial perception, spatial visualization, and mathematical achievement (Zembar \& Blume, 2011). 
b. Male's and Female's Brain

Neurology research found that for some cases female's brain is superior (Chaer, 2009: 133). It is proved by female's brain have different function with males, and those difference make female superior.

1) Female's brain is more balance

Even though male's and female's brain do the same work, the mechanism of both of them are different. It caused by the difference of density of neuron in a part of brain. Female's brain has more neuron at the language center (part of brain that process language). Some expert conjecture the cause of female superior in speaking, reading, and seldom get the study disorder is because the ability of female to use her two hemispheres (left and right when read or do other verbal activities). While the male only use one of hemispheres.

2) Female's brain is keener

Dr. Thomas Crook states that memory of male is less keen than females. He found that female remember more about detail, association, and her private experience than male. Male and female will undergo the degradation of memory. But female's memory about vocabularies and names is lasting than males, because female's brain has unique way to save information to her memory in emotion part. Female uses her right hemisphere more (to process emotion so the data is saved in memory part automatically. Female's brain is more lasting and selective.

According to Ruben Gur, male's brain frown three times faster than females. This frown makes exact change such as less in memory, concentration, and the patient. In addition, Ruben states that the frown of male's brain correlate with the usage of energy. Female's brain has the ability to adapt the speed of brain's metabolism with her old, while the male metabolism is wasteful energy more and more.

\section{Reading}

a. Definition of Reading

Reading has different definitions for each people. According to Patricia L. Carrel and William Grabe reading is a cognitive process and knowledge resources relate to the ability to achieve information from the text (Carell \& Grabe, 2010: 213). Another opinion defines that reading is a complex act requiring among other things, specific ability and certain skill (Thonis, 1970: 67). Reading is a complex skill(Broughton, Brumfit, Flavell, Hill, \& Pincas, 2003: 89-90).

As a complex skill it involves some components, these are the recognition of the black marks, the correlation of these with formal linguistics elements, and the correlation of the result with meaning. And Nunan defines reading is usually conceived of as a solitary which the reader interacts with the text in isolation (Nunan, 1991: 72). 
b. The Kinds of Reading

According to Broughton (2003: 93) there are two kinds of reading, these are:

1) Intensive Reading

Intensive reading focuses on the construction of reading texts which takes place usually in classroom (but not always). Teacher may ask students to look at text from magazines, newspapers, poems, novels, internet websites or other text genres. The exact choice of genres and topics may be determined by the specific purpose that students are studying for. The objective of intensive reading is developing the ability to decode meaning or messages by drawing on both syntactical and lexical clues.

2) Extensive reading

Extensive reading focuses on the construction of reading text which takes place usually away from the classroom (but not always). It should involve reading for pleasure. Students have a chance to choose what they want to read. They may read novels, magazines, newspapers, and other references materials. It is intended to develop good reading habit.

c. Reading Principle

Reading has some principles, those are (Harmer, 2010: 101)

1) Encourage students as often and as much as possible.

2) Students need to be engaged with what they are reading.

3) Encourage students to respond to the content of the text (and explore their feelings about it), not just concentrate on its construction.

4) Prediction is the major factor in reading.

5) Match the task to the topic when using intensive reading texts.

6) Good teachers exploit reading texts to the full.

\section{Reading Comprehension}

a. Definition of Reading Comprehension

Reading comprehension is the process of constructing meaning by integrating the information provided by an author with a reader's background knowledge (Vaughn \& S. Bos, 2012: 248). When the reader interacts with the text to construct the meaning, it involves complex cognitive skills and strategies. The comprehension process entails ongoing transactions between a text, the reader, and the author and the active use of comprehension strategies such as predicting, activating background knowledge, asking questions, clarifying, and checking for understanding (Vaughn \& S. Bos, 2012: 250). Those statements show us that comprehension is the most important thing and the final goal of reading instruction. 
Kimsiyatur Rahmawati, and S. Sumihatul Ummah MS, The Comparison Between Male ...

b. The Level of Comprehension in Reading

In constructing the meaning of a text, the students may engage in different types or levels of thinking. Three levels of comprehension are typically identified: literal, inferential, and critical (Scanlon, Anderson, \& Sweeney, 2010: 278).

1) Literal Comprehension

At this level the reader or the students can understand information stated directly in the text, but it only surface understanding. Tests in this category are objective. Common question used in this level of thinking are who, what, when, and where question.

2) Inferential Comprehension

At this level the reader or the students should making inferences that bridge the information directly stated in the text with information that the reader already possesses. Tests in this category are subjective. Common questions asked are open- ended, thought provoking questions like why, what if, and how.

3) Critical Comprehension

At this level the reader should evaluating the information in the text relative to what it means to the reader and relative to the intentions, expertise, and perspective of the author.

c. The Difficulties of Reading Comprehension

Comprehension relies on mastery of decoding. Students who struggle to decode find it difficult to understand and remember what has been read. Because their effort to understand the individual word, they tend to allocate so much attention to word identification and neglecting to construct the meaning. Signs of comprehension difficulty ('Misunderstood Minds. Reading Difficulties | PBS', n.d.):

1) Confusion about the meaning of words and sentences.

2) Inability to connect ideas in a passage.

3) Omission of or glossing over detail.

4) Difficulty distinguishing significant information from minor details.

5) Lack of concentration during reading.

d. Strategies for Reading Comprehension

Comprehension is the most important thing in reading. The teacher should provide appropriate strategies to teach students for faster and better comprehension (Vaughn \& $\mathrm{S}$. Bos, 2012: 251-252), there are some comprehension strategies, those are:

1) Activating background knowledge

2) Pre-teaching critical vocabulary and concepts

3) Generating question

4) Monitoring comprehension

5) Clarifying 
6) Using graphic organizers

7) Finding main ideas

8) Summarizing

9) Using text structure

\section{METHOD}

This research will use quantitative approach, and the design of this research ex-post facto or causal comparative research. Causal comparative research measures the cause and effect relationship without manipulating the independent variables. It starts from identifying the existing conditions and proceeds to find the cause of the conditions. In this study, male and female students is become independent variable. And reading comprehension achievement is become dependent variable. The researcher wants to conduct causal comparative research to investigate the difference achievement between male and female students in reading comprehension.

The population was the students of reading 3 subject of the third semester of TBI STAIN Pamekasan. It consists of six classes. Namely A class consist of 24 students, B class consist of 40 students, C class consist of 35 students, D class consist of 29 students, E class consist of 40 students, and $\mathrm{F}$ class consist of 42 students. The total number of population is 210 students. The researcher took $20 \%$ of the population to get more fair result. $20 \%$ of the population is 42 students. So, the researcher took 42 students for each group. The technique of sampling that was used in this study is stratified sampling. According to Creswell, (2012: 144), it is a quantitative sampling procedure in which researchers stratify the population on some specific characteristic (e.g., gender and then sample, using simple random sampling, from each stratum of the population).

Research instrument which is used in this research are test and documentation. The steps that will use by the researcher to collect data are: 1) Test: The test was asking the students to answer the reading comprehension test in form of essay tests. The researcher will not provide the multiple choices because the researcher wants to know the real achievement of students in reading comprehension. The score of each item will be different based on the difficulty of the answer. The item that has more difficult answer will get higher score. There are two passages and eight items for each passage in this test. 2) Documentation: Documentation in this research is the students name list, reading test work sheet, key answer of reading test and photos of students. To analyze the data in this study, the researcher used inferential analysis, namely $t$-test.

\section{RESULTS AND DISCUSSION}

\section{Results}

After measuring the validity of the test, the researcher conducted a research by giving a test to some respondents, while the test is assessing them to answer the 
questions of the reading comprehension in form of essay test. Then, the researcher scored them by scale score. Then the researcher analyzed the reading comprehension test score by using statistical form, comparative study. In comparing the scores of both groups, that is male and female students the researcher applied the formula of independent t-test theory. The researcher identifies the $\mathrm{X}_{1}$ as (male students) and $\mathrm{X}_{2}$ (female Students).

From the result of independent t-test. It is found that the $t$-value is $-1,226$. To determine whether null hypothesis is received or rejected. The researcher goes to the next step namely hypothesis testing.

Hypothesis testing is testing the hypothesis by consulting t-values to $t$ - table. The researcher test the hypothesis of this research, this test is to prove whether the hypothesis, alternative hypothesis (Ha which is used in this research is accepted or rejected. Anas states if $t$-value $\left(t_{0}\right.$ is same as or higher than $t$-table, the null hypothesis $\left(\mathrm{H}_{0}\right.$ is rejected. In contrast, if $t$-value $\left(t_{0}\right.$ is lower than $t$-table, the null hypothesis is accepted (Sudijono, 2011: 284-285). It means that, the alternative hypothesis (Ha will be accepted if $t$-value $\left(t_{0}\right)$ is higher than $t$-table, and will be rejected if $t$-value $\left(t_{0}\right.$ is lower than t-table. Moreover, the hypothesis of this research is alternative hypothesis $\left(\mathrm{H}_{\mathrm{a}}\right.$ that states that there is different achievement in reading comprehension between male and female students at the third semester of TBI STAIN Pamekasan. To decide whether alternative hypothesis ( $\mathrm{Ha}$ is accepted or rejected, the researcher consulted $\mathrm{t}$-value of this research to t-table with the degree of freedom $\mathrm{df}(\mathrm{N} 1+\mathrm{N} 2)-2$. The researcher should find the sum of the degree of freedom first in the following calculation. As it is known that $\mathrm{N} 1$ is 42 and $\mathrm{N} 2$ is 42 .

So, the degree of freedom is $(42+42)-2=82$. Thus the researcher should find out the degree of freedom, value of 82 in the table critical value " $t$ ". However, the value of 82 is not in the table critical value " $t$ ". So the researcher chooses the closest figures to 82 , namely 80 in the table critical value " $\mathrm{t}$ ". Based on the table critical value " $\mathrm{t}$ ", the t-table in significant level $1 \%$ is 2.64 with the degree of freedom 80 . However, the $t$-value of this research is -1.226 . After consulting t-value to t-table, it can be known that $\mathrm{t}$-value of this research is lower than $\mathrm{t}$-table in significant $1 \%$ ( $\mathrm{t}$-value $<\mathrm{t}$-table or $-1,226<2.64$ ). In significant $5 \%$ the $t$-value is also lower than $t$-table, since the t-table in significant $5 \%$ is 1.99 ( $\mathrm{t}$-value $<\mathrm{t}$-table or $-1,226<1.99$ ). Therefore, the alternative hypothesis that is used in this research fails to be accepted. It means that the null hypothesis is firmly accepted.

\section{Discussion}

As the explanation in the background of study that some study found that there is difference achievement between male and female students in reading comprehension achievement. The researcher formulates two research problems in which all of need to be answered of this research. The researcher analyzed the reading comprehensions 
score of both groups male and female students by using t-test formula and committed hypothesis testing. After knowing the results, the answers they are:

There is no difference achievement in reading comprehension between male and female students at the third semester of TBI STAIN Pamekasan. It can be proved by the analyzing and knowing the means scores of both two groups, as the mean score of male students is 57.714 and the mean score of female students is 61.05. The mean score 57.714 which is got by the male students can be inferred that it is representative of reading comprehension of the population of male students and the mean score 61.05 which is got by the female students can be inferred that it is representative of reading comprehension of the population of female students. In addition, it is also by knowing the $t$-value that $t$-value is lower than $t$-table in significant level $1 \%$ and $5 \%$.

In short, based on the description of the means scores and $t$-value above, the researcher infers that there is no difference achievement in reading comprehension between male and female students at the third semester of TBI STAIN Pamekasan. This is an answer of the first research problem.

The current finding of this research, male and female students do not have difference achievement in reading comprehension. It is contras with the finding of some study such as PIRLS (Progress in International Reading Literacy Study) and PISA (Program for International Students Assessment) that found that female students achieve better reading comprehension than male students. And also the theory of psycholinguistics in Abdul Chaer book that states, the area of female brain that concern with the high level of cognitive skill such as the ability in language has more neuron than males (Chaer, 2009: 134). The function of brain will be strong more and more if the area of brain has more neuron. It is supported with the description of Harasty, Double, Halliday, Kril and McRitchie that the volume of female's brain in language area is bigger than male. So, naturally female has a great possibility to be superior in term of language because her brain has provided it for her. Even it should be done for every female to show their strength.

Furthermore, some experts state that female are superior than male in speaking, reading and seldom to get learning disorder because female can use both of their hemisphere (left and right when reading or doing verbal activity (Janson, 2010: 53). By the some superiority of the female's brain it should for females to aware and apply their brain potential greatly and optimally. But, in fact, not all females aware and exploit it greatly. As the researcher found in her study that there is no difference achievement in reading comprehension between male and female students at the third semester of TBI STAIN Pamekasan.

Both groups of male and female students at the third semester of TBI STAIN Pamekasan are not statistically significant difference in reading comprehension achievement since it has been seen that $t$-value is lower than t-table in both significant 
level $1 \%$ and $5 \%$. It is proven by the hypothesis testing of this research is fail to be accepted in significant level1\% and 5\%. In proving the hypothesis, the researcher consults $t$-value of this research to t-table. The $t$-value of this research is -1.226 , moreover, t-table is 2.64 in significant $1 \%$ and 1.99 in significant $5 \%$ with the degree of freedom 80. So, the researcher chooses the degree of freedom which is closest to 82 , that is 80 which has value of t- table 2.64 in significant $1 \%$ and 1.99 in significant $5 \%$.

Thus, it can be seen that $\mathrm{t}$-value is lower than $\mathrm{t}$-table in significant level $1 \%$ (t-value < t-table or $-1,226<2.46$ ), and in significant $5 \%$ (t-value $<$ t-table or $-1.226<1.99$ ). Therefore, the answer of the second research problem is there is not statistical significant difference between male and female students at the third semester of TBI STAIN Pamekasan in reading comprehension achievement in significant level 1\% and 5\%.

\section{CONCLUSION}

There is no difference achievement in reading comprehension between male and female students at the third semester of TBI STAIN Pamekasan since female students could not aware and apply their brain potential to be superior in term of language learning including in reading comprehension. From the result of data analysis that has been analyzed by the researcher, it denotes that there is not statistical significant difference between male and female students at the third semester of TBI STAIN Pamekasan in reading comprehension achievement in significant level $1 \%$ and $5 \%$. It is proven by the result of data analysis and by comparing t-value with t-table in significant $1 \%$ and $5 \%$. The result denotes that $t$-value is $-1,226$ whereas $t$-table is 2,46 in significant level $1 \%$ and 1,99 in significant $5 \%$. Therefore, $t$-value is lower than $t$-table in both significant level $1 \%$ and $5 \%$.

\section{REFERENCES}

Al-Shumaimeri, Y.A. (2005). Gender Differences in Reading Comprehension Performance in Relation to Content Familiarity of Gender-Neutral Texts. Presented at the Second International Conference: Language, Culture and Literature., Minia University, Egypt.

Broughton, G., Brumfit, C., Flavell, R., Hill, P., \& Pincas, A. (2003). Geoffrey Broughton, et. al, Teaching English as a Foreign Language (Taylor and Francis: Routledge, 2003), 8990. London and New York: Routledge.

Carell, P., \& Grabe, W. (2010). An Introduction to Applied Linguistics. London: Hodder Education.

Chaer, A. (2009). Psikolinguistik Kajian Teoritik. Jakarta: Rineka Cipta.

Creswell, J. W. (2012). Educational Research: Planning, Conducting and Evaluating Quantitative and Qualitative Research. USA: Pearson Education.

Ellis, R. (1994). The Study of Second Language Acquisition. Oxford: Oxford University Press. 
Harmer, J. (2010). How to Teach English. England: Pearson Education.

Hidayah, R. (2012). Profil Kemampuan Membaca Siswa Kelas 5 Sekolah Dasar (Sd) dan Madrasah Ibtidaiyah (Mi) Ditinjau dari Jenis Sekolah dan Jenis Kelamin. Universitas Islam Negeri Maulana Malik Ibrahim.

Holmes, J. (2001). An Introduction to Sociolinguistics. Harlow: Longman.

Janson, E. (2010). Guru Super and Super Teaching. Jakarta: PT Indeks.

Lynn, R., \& Mikk, J. (2009). Sex Differences in Reading Achievement. Trames, (13), 3-13.

Nunan, D. (1991). Language Teaching Methodology: A textbook for teachers. New York: Prentice Hall International.

Scanlon, D. M., Anderson, K. L., \& Sweeney, J. M. (2010). Early Intervention for Reading Difficulties: The Interactive Strategies Approach. New York: The Guilford Press.

Sudijono, A. (2011). Pengantar Statistik Pendidikan. Jakarta: Rajawali Press.

Thonis, E. W. (1970). Teaching Reading to Non-English Speakers. New York: Collier Macmillan Publisher.

Vaughn, S. R., \& S. Bos, C. (2012). Strategies for Teaching Students with Learning and Behavior Problems. New Jersey: Pearson Education.

Zembar, L. B., \& Blume, L. B. (2011). Gender and Academic Achievement. Retrieved from www.education .com/Reference/Article/Gendertoacademytoachievement 